\title{
19th Century Bengali Women and the Films of Satyajit Ray: A study
}

\author{
Monalisa Bhattacherjee \\ Assistant Professor, Department of Political Science, Serampore College, Hoogly, West Bengal, India
}

\begin{abstract}
The present study has determined to explore the condition of 19th century Bengali women by analysing the cinemas of Satyajit Ray. In the 19th century social life of Bengali women was marked as a transition period of their developments. In the first half of this century the women as was confined to social disciplines, on the contrary it was evident that in the works of contemporary Bengali stalwarts social upliftment of women was seen. Although starting of women's liberation from social disciplines started in the second half of the 19th century, the Bengali writers published important truth about these liberations in their contemporary writing. In the composition of 'Debi' of Pravat Kumar Mukhopadhyay and 'Nastanir' of Rabindranath Tagore two different types of pictures were found. In 'Debi' story in the first half of the 19th century social discipline of Bengali women and on the other side in 'Nastanir' novel in the second half of 19th century social liberation of women was pictured by Satyajit Ray centering these two subject 'Debi' and 'Charulata' cinemas. In this research article I have chosen two films of the great director Satyajit Ray such as 'Debi' and 'Charulata' to compare them with the condition of the 19th century Bengali women.
\end{abstract}

Keywords: Film and Society,Bengali Society, Bengali Women, Bengali Film, Satyajit Ray's Cinema, Women in Film

\section{Introduction}

In the 19th century new waking of Bengal created new excitement among the Bengali women and as a result a new social reformation took place between them. Although this reformation was tried in the first part of the 19th century but the actual time of women upliftment was started from the second half of that century. Long standing superstitious women felt that their destiny was to accept these conditions without any protest. Being encircled with the prevalent superstitious conditions they failed to tear the-then systems although some men were educated in the first part of the 19th century. In the first part of the 19th century with the background of Bengali society the 'Debi' filmed by Satyajit Roy exposed the-then wretched conditions of women in the society. Through this 'Debi' cinema Satyajit Roy wanted to vehemently strike against religious arousal and superstition when the Western education system enlightened India then Satyajit tried to expose the superstitious men.

A change took place in the second half of 19th century regarding the conditions of women for the reason of spreading education amongst the women through education women class felt the taste of freedom. They established strongly their positions in the families. At this time it was seen that the women tried to establish their social existence breaking the social limit. Satyajit Roy tried to highlight the changing circumstances through his 'Charulata' cinema. In fact 'Charu' of 'Charulata' cinema was a literate woman of the second half of the 19th century. She learnt how to give importance in their own rights and dignity and she had the power to equalize with the qualities of Bhupati or Amal. About the films of Satyajit Ray film critic Shyam Dua wrote that, "Satyajit had portrayed Indian women in the milieu of sensitive time and space in his films".

\section{SOCIAL LIMITATIONS OF WOMEN}

In an ancient Vedic age similar position of men and women was admitted. Although paternity was in existence in the society but sons and daughters were considered in equal status. Especially after writing of Manu Sangita in the later part of Vedic age the position of women became downward. The role of women in educational field was restricted and thus the women became housewives. In the middle age the very 'Purdah protha' of both Hindu and Muslim women made them prey to the superiority of male generative in the society. At the same time institutions of descent nobility downgraded the position of women in the society for polygamy of male persons. According to J.P.Saikia " Evil social practices, dogmatic religious beliefs, inhuman superstitions and sinister customs caused the maximum degree of deterioration. Child marriage, Devdasi, Sati, enforced widowhood, purdah, dowry, female infanticide and the practice of polygamy made the Indian society static".

In the eighteenth century and in the first half of the 19th century the dignity of women became more downward in the society. Although in the first half of that century western education took place in the society 
19th Century Bengali Women and the Films of Satyajit Ray: A study

but the women were deprived of from that education system. A few number of educated persons in 1830 and 1840 decades tried to educate their women members of their family in a secret way in small no's. But prior to 1849 no formal school was established for the women of gentlemen's families. And even after that, by denying the Pardah Customs the gentlemen hesitated to send their daughters to school and for which they took some time for taking decisions in the matter. But all these gentlemen were educated in western methods of education and accordingly they were accustomed to the idea 'Women's position could be used as an indicator of society's advancement'. In spite of that in the first half of the 19th century all these educated persons of western education system could not enlightened the women members. The paternal society was much more responsible thus far. In the families paternity was so tightly established their domination. As a result,"the status of Indian women was deteriorating gradually. Ultimately they totally became the slave of man and got imprisoned inside the four walls of the house".

Adopting the 'Debi' story of Pravat Kumar Mukhopadhay Satyajit pictured the background of Bengal in the first half of the 19th century, when entire society was governed by unobstructed paternity. At that time in Bengal when there was a religious superstitious culture and orthodox ignorance, on the other side there were some youths who were educated in English literature. 'Debi' was the story of a housewife of one Landlord family of that age, when a collision between two contradictory ideas took place which created tragedy in the society. In one side fanatic father in laws and on the other side half reasoned husband - collision between these two contradictory ideas beat the kind hearted women. In cinema Satyajit Roy portrayed the character of Kalikinkar as a symbol of paternity. Where powerful landlords imposed the mask of the Goddess like image on Dayamayee for substantiating their imaginations. Federalist mates exploited the women to fulfil their religious desires, on the other side half framed modern males were trying in a failure method to face the women.

In cinema landlord Kalikinkar dreamt his very much fonded daughter-in- law in the shape of Kalimata (Hindu Deity). As a result, theisms Kalikinkar imposed holiness on his daughter in law Dayamayee for which it was not possible for him to break the superstitious fence. For which he could not avoid his ultimate death in the last part of the film. Limitations of the colonial education system clearly showed that in spite of being educated in western education Umaprasad could not free his wife from unrealistic blind belief. His friend of Calcutta Bhudeb while wanted to marry a widow Umaprasad supported him in the matter. He also wanted to make the debate with the father of his friend and told that he would convince him in the matter. He showed nails of his fingers and told that all arguments of Sir Vidyasagar were with him. But he even failed to convince his wife Dayamayee that she was a human being, not an incarnation of God. Umaprasad could not bring his wife Dayamayee to Calcutta in spite of his strong belief. His fragile arguments, progressive mind could not cross the limit of middle class families enlightened with Colonial structure. In the framework of the film it was evident that arguments could not enter into the lives of families.

Although Umaprasad debated with his father Kalikinkar regarding Godness of Dayamayee but in no time while he failed the clue of the said debate then dying children were taking foot water of Dayamayee (Debi) to remain alive. Naturally acquaintance of Dayamayee as Debi became unquestionable and prevalent culture and her pious and clear mind sorely wounded with strong intuition. In spite of numerous arguments of Umaprasad, Dayamayee always think, "If I am actually 'Debi'!" In the first half of the 19th century in the story of English Missionaries Hindu Religion. The main object of these criticisms was to preach the greatness of Christianity, not to cooperate with social reforms. If that happened in that case Dayamayee would not have been confined with a girdle of gods. In this context has a pathetic tragedy of century old Hindu billets. Fleeing from religious superstition two young men and young women wanted to enjoy their life. But being a failure in tearing the noose of serpents of religious customs they had to agree with their destiny. At last in the life of Dayamayee tragedy came.

To 'Debi' film the portrait of women which was shown, in that context supremacy of paternity was there. The elder son of Taraprasad of landlord Kalikinkar was compelled to admit Dayamayee as 'Debi' as imposed by his father. The arguments of Umaprasad taught him to fight against superstition. On the other hand the realism of Taraprasad helped him to keep alive his superstitious mind in his own interest. The other women of film 'Debi', the wife of Taraprasad was a common knowledgeable housewife and who seeing the activities of all males around her and also being shown of Ceremonial Waving of lights before the duties she was shocked. If any child became ill she denying the paternity with great risk called doctors but ultimately she had to take shelter of divine power and as a result it reserved the Renaissance of the 19th century.

In the first half of 19th century colonial education system unveiled the middle class society in Calcutta who tried side by side to reform the social structure and social upliftment of women. But that attempt also was limited to a certain boundary. Actually in the first half of the 19th century the women class did not give their assent to the attempt of educated gentlemen for upliftment of women. They loved to resort the long practiced traditions. The women who were enlightened in educations were confined within their houses. Naturally although they could write letters but the women like Dayamayee had no possibility to acquire the arguments raised by others. On the other hand the influences of the Renaissance of the 19th century took place in the 
thoughts and beliefs of Umaprasad. Although he had the belief in his own thoughts but those thoughts were not strong enough.

In the context of Indian Culture 'Debi' was a revolutionary film. Throughout the hundred of years the religion which was practiced in rural villages, that religion was challenged in the film. At the same time it was not possible to challenge the absolute power of paternity which psychologist Richard Lanoy said about absolute power of paternity in Indian society that, "In our country the father is still not a family friend, but a dictator...culturally we expect the father to be a sort of authority, and every member of the family must try to keep him happy. The family is ready to accept this type of dictatorship". Naturally it was easy for Kalikinkar to establish Dayamayee as an incarnation of the goddess. He was the main personality of the family and society, whose saying and instructions had to be followed by all blindly. As it was not possible for Taraprasad to disobey the instructions of his father. Even he did not hesitate to bow down his head before the wife of his younger brother. As a result it was not possible for Dayamayee to come out from the influence of paternity and from the well practiced structure of Indian society's colonial selfishness.

\section{SOCIAL UPLIFTMENT OF WOMEN}

Satyajit Roy directed the film 'Charulata' adopting the story 'Nastonir' written by Rabindranath Thakur. Satyajit directed the said film basing on his own thoughts although the story 'Nastonir' was followed by Rabindra writings. The attempt of upliftment from the limitations of 19th century in one side and on the other side pointed attention towards women's progress helped the film 'Charulata' to reach its highest peak. 'Charulata' was not only a picture of solitary women, the social status of the second half of the 19th century and the position of women were pictured with modern outlook. Although Rabindranath did not give any clear idea about the time of 'Nastonir' story but it was presumed that the time was the second half of the 19th century. Satyajit Roy gave importance on social upliftment of women in his 'Charulata' film in the years of the 80's of the 19th century and at the same time expressed the status of a Bengali society of the 19th century.

In 19th century social upliftment of woman's outlook took a strong shape after a speech delivered by Justice Fiyar in 'Bengal Social Science Association' hall. At this meeting Fiyar told that, if you like to keep intact the dignity which you had acquired, if you like to forward the country's welfare outside your country, in that case please extend your hands to wives and daughters, and promote them to your high level. The main male character of 'Charulata' film western educated Bhupati wanted to see in his wife 'Charulata' as a modern educated woman. And for this Bhupati wanted to take help from Amal to awaken the writer's ideas within Charulata. In the 19th century Gulam Murshid wrote about woman's thoughts, "the freedom movement of Bengali women was started by the males". Hence, in the true sense, this movement was not fully independent to make free the women from the role of males. In opposite, rather to say, the males started this movement to make their own world partially modern.

Although the males forwarded for women progress in their own interest but it is to be admitted that self interest helped in the matter of women's development. In the first half of $19^{\text {th }}$ century moves were started for upliftment of the social status of women, in that process although the subject of women's education was the main object of the list but there was no preparation of women's true education before establishment of Bethun School in 1849. In Bengal, the beginning of women's education was started from the campus of the Calcutta Female School established by Bethun and that beginning was started only with two girls. In 1854 was the preface of Charles Wood which was regarded as attributed importance on women's education. Inside education side by side customary education made progress in equal nature. Naturally, before the women the chances of being educated helped Charulata to become educated.

In the second half of the 19th century Charulata became educated due to increase in numbers of educated gentleman in the society. At the same time education of Bengali literature became effective. Eminent social scientist Partho Chattacherjee had written, "The development of an educative literature and teaching materials in the Bengali language undoubtedly made possible the quit general acceptance of formal education among middle class women". In the second half of the 19th century the writings of women began to publish. Not only essays, books and autobiographical compositions were also published. Kumudini Roy, Gnandanandini Debi, Kamini Dutta all these enlightened women although appeared but they could not come out from prevalent religious sentiments. In 1861 and 1864 respectively in the writings in respect of 'Hindu Samaje Mohilader Abosthan' of Bamasundary Debi and Kailash Basini Debi reflection of self satisfaction was revealed. But 'Sekeler Katha' of Nistarinyi Debi was "unique in that sense as it is the only one that provided insights into the dynamics of Kulinism and how it affected families", in that time the Bengali women were asking questions regarding prevalent social conditions and their position in the society.

In the second half of the 19th century with the attempt of social reformers good results were being available on women's progress. At that time in the publications of writing by women which made the advancement of qualities in their writings. The writings of women were not only limited their life story. In the second half of the 19th century in different publications on women their expertness became more increased gradually. According Forbes "Formal education and particularly the development of publications intended for 
19th Century Bengali Women and the Films of Satyajit Ray: A study

and written by women gave women a voice". We had seen that in 'Charulata' film an essay written by Charu in the style of 'Biswabandhu' was published in a main magazine of Bengali literary world. In this context, it is to be said Amal could not dare to publish his writings in 'Biswabandhu' magazine, because in that magazine only famous writers were given scope. Again for the victory festival of Liberals (British political party) in the house of Bhupati the importance of that magazine and good reputation of writer Charu were introduced. The writing of Charu in the style of 'my village' it was indicated that the greater world of thoughts of women crossed certain limits. Naturally it is to be said that the independent thoughts of women got courage to cross the social limits in the second half of the 19th century.

In the second half of the 19th century through influence of Western education a radical change took place in the livelihood of Bengali males. The males started to feel the urge to get their wives as mental companion keeping aside the traditional idea regarding women. The inevitable result of which a new chapter in the love life of Bengalis was introduced in relation to male and female in the society. From 60s of the 19th century romantic thoughts not only influenced the literature but also individual lives. There is no doubt that in the 70s and 80s of 19th century modern educated women were not influenced in western romanticism like males but romantic thoughts in Bengali novels influenced the women in romanticism. This romantic thought of 19th century infused Charulata and crossing the legal bounds it created mental complexity. Amal appeared as her life companion in the lonely life of Charulata. It was not possible for Charulata to take mental part in larger working field of Bhupoti. Her attention was concentrated in Amal. Charu broke early social boundaries quite ignorantly. Charu loved that male who accompanied her in a critical time of her life. By loving Amal, Charu discovered herself in a new way. And rightly in this place Satyajit bypassing time expressed the inner qualities, beauty, honesty and compactness of woman's character through gradual consequences in self lives of women.

The attraction of Charulata to Amal was although illicit in so called ethical Hindu society but fair, because it opened the delicate stratums of a feeling of inclined mind. The real delicacy of a woman's character, intelligence and charming beauty remained hidden for relation with Amal and all those romantic consciousness were expressed fully. Satyajit actually within all these powers, individual independence and characteristics strangeness did not deny the honesty of women. He never bypassed their health and natural acceptable subjects. Rather through all these things Satyajit discovered an upliftment of women through in the 19th century. Rabindranath wrote a letter to Murari Bhadury who was the younger brother of Sisir Kumar Bhadury, the theatrical master, in the wordless age of the films, "the films still now flattering the literature because no rhetorical figure could not rescue that with his own talent from slavery." There is no doubt in the matter that Satyajit could make free the films from the slavery of literature.

\section{CONCLUSION}

This is to be admitted that in 19th century Bengal there were many in complete things within idealism of free women. The great cause of this that in the $1^{\text {st }}$ half of the 19 th century the males being educated in western education made progress towards upliftment of women. In another way it is to be said that the movements of women's freedom in the whole was guided by males. Lagging behind the traditional customs no mentality was grown within Hindu religious women society to move towards upliftment of their conditions. Over and above that the males earned the thoughts of women's freedom from western education. In this stage the western countries also could not come out from paternity. Naturally it was not possible for Bengali males, although educated in Western education, to equalize socially by eradicating paternity. In one side religions customs and in other side the social structure governed by parents, compelled the women to stay in their homes in the first half of the 19th century. Through 'Debi' film Satyajit Ray defrauding of women of this chapter, trial for imposing deviousness upon women for fulfilling the interests of orthodox people and to open the unobstructed power of paternity, when the western educated man like Umaprasad also admitted to the challenges of orthodox people.

'Charulata' although a story of the 19th century was more modern in mentality. Charu had no offensive mind. The man in whose touch awakened her sleep when he did not admit the responsibility of awakening like cowards, then she held the hands of her husband; because she had to live in any way. A power of her inner mind ignorantly pushed her to acuteness for a living. Here from traditional women hood with the urge of any social power they took the path of upliftment of modernity. But the time was still far away and for that reason the steps came back from the doors. Actually Satyajit although lived in a family atmosphere with Victorian customs but was also familiar with all sides of Indian tradition and became reanimated with modern ideas of that time. For which he pained the woman's character according to their own markings, he did not try to follow the clues of the spiritual truth of women hood. 


\section{Journal Papers:}

\section{REFERENCES}

[1] Ramnarayan Gouri, Walking tall: On Satyajit Ray and his style, Frontline, 20 December, 1991.

[2] Statyajit Ray Special Number, Montage, Anandam Film Society, Bombay, 1966.

[3] Houston Penelope, Ray's Charulata, Sight \& Sound, 35(1), Winter-1965-66.

[4] Chatterjee Partha, Colonialism, Nationalism and Colonized Women: The Quest in India, American Ethnologists, 16(2), 1989.

[5] Ghosh Bishnupriya, Satyajit Ray’s Devi: Constructing a Third -World Feminist Critique, Screen, 33(2), Summer 1992.

[6] Ganguly Keya, Carnal Knowledge: Visuality and the Modern in Charulata, Camera Obscura, 37, January-1996.

[7] Biswas Moinak, Bengali Film Debates: The Literary Liason Revisited, Journal of Moving Image, 1(1), 1999.

[8] Sil Narasingha P., Tagore's Broken Nest vs. Ray's Charulata: A Critique, Asian Cinema, 10(2), 1999.

[9] Kapur Geeta, Cultural Creativity in the First Decade: The Example of Satyajit Ray, Journal of Arts and Ideas, 23(4), January1993.

\section{Books:}

[10] Banerjee Surabhi, Satyajit Ray: Beyond the Frame, (New Delhi: Allied Publishers, 1996).

[11] Biswas Pradip, Ray on Ray, (Kolkata: Dasgupta \& Company Private Limited, 2008).

[12] Cowie Peter. A Concise History of the Cinema 2 Vols., (London: A.Wemmer Ltd., 1971).

[13] Dasgupta Chidananda The Cinema of Satyajit Ray, (New Delhi: Vikas Pub., 1980).

[14] Dasgupta Chidananda (ed.), Film India: Satyajit Ray, (New Delhi: Directorate of Film Festivals, 1981).

[15] Das Santi, Satyajit Ray: An intimate master, (Calcutta: Papyrus, 1998).

[16] Dua Shyam, The Luminous Life of Satyjit Ray, (Delhi: Printline Books, 2004).

[17] Duttagupta Bela, Sociology in India, (Calcutta: Centre for Sociological Research, 1981)

[18] Forbes Geraldine, Women In Modern India, (London: Cambridge University Press, 1974).

[19] Ganguly Suranjan, Satyajit Ray: In Search of the Modern, (Lanham: Scarecrow Press, 2000).

[20] Houston Penelope, The Contemporary Cinema, ( Harmondworth: Pelican, 1968).

[21] Kael Pauline. Deeper Movies, (Boston: Little Brown, 1973).

[22] Karlekar M., Voices from Within - Early Personal Narratives of Bengali Women, (New Delhi: OUP, 1991).

[23] Lannoy Richard, The Speaking Tree, (London: OUP, 1974).

[24] Mishra Saraswati, Status of Indian Women, ( Gyan Publishing House, New Delhi, 2002).

[25] Murshid Ghulam, Reluctant Debutante: Response of Bengali Women to Modernization, 1849-1905, (Sahitya Samsad, Rajshahi University, 1983).

[26] Nyce Ben, Satyajit ray, A Study of His Films, Praeger Publisher, New York, 1988).

[27] Robinson Andrew, Satyajit Ray: The Inner Eye, (New Delhi: OUP, 2004).

[28] Sarkar Bidyut, The World of Satyajit Ray, ( New Delhi: UBSPD, 1992).

[29] Seaton Marie, Portrait of a Director: Satyajit Ray, (New Delhi: Penguin Books India, Revised edition- 2003).

[30] Saikia J.P., Problems of Education and Rural Women, (Guwahati: DVS Publishers, 2008).

[31] Taylor Jhon Russell, Directors and Directions : Cinema for the Seventies, (London: Eyre Methuen, 1971).

[32] Thoraval Yves, The Cinema of India (1896-2000), (New Delhi: Macmillan, 2000).

[33] Valicha Kishore, The Moving Image: A Study of Indian Cinema, (Hyderabad: Orient Longman, Reprint-1999).

\section{Chapters in Books:}

[34] Holland, Norman, Ray's Devi, in Patrick Colm Hogan and Lalita Pandit (Ed.), Literary India: Comparatives Studies in Aesthetics, Colonialism and Culture, (Albany: SUNY Press, 1995).

[35] Nandy Ashis, Satyajit Ray's Secret Guide to Exqusite Murders: Creativity, Social Criticism, and the Partitioning of the Self, In Ashis Nandy (Ed.), The Savage Freud and other Essays on Possible and Retrievable Selves, (New Delhi: OUP, 1995).

[36] Dirks, Nicholas B, The Sovereignty of History: Culture and Modernity in the Cinema of Satyajit Ray, In, Timothy Mitchell (Ed.), Questions of Modernity Minneapolis, (Minnesota :University of Minnesota Press, 2000). 